Jurnal Tarbawi: Jurnal Ilmu Pendidikan

p-ISSN:1858-1080 | e-ISSN: 2615-6547

Vol. 15, No. 02, Desember 2019, pp. 171-191

\title{
Evaluasi Manajemen Wellness Center Pegawai PT. Pertamina Gas Jakarta
}

\author{
Nourma Try Indriani ${ }^{1}$, James Tangkudung ${ }^{2}$, Hidayat Humaid $^{3}$ \\ 1,2,3 Universitas Negeri Jakarta \\ e-mail: indrianint@gmail.com
}

\begin{abstract}
The aim oh this research is to obtain information about the management of Wellness Center employees of PT. Pertamina Gas Jakarta. This evaluation study uses a Mix-Method research method with an evaluation model approach Context, Input, Process, Product (CIPP). Data collection is done by interview, observation and documentation study. The results of the study concluded that: (1). The evaluation component found at the context stage was assessed as good (68.15\%). (2). The evaluation component found at the input stage is considered sufficient $(58.76 \%)$. (3). The evaluation component contained in the process stages was assessed as lacking (55.17\%). (4). The evaluation component found in the product stage is considered very poor $(37.14 \%)$. Overall the results of the evaluation of the management of the Wellness Center employees of PT. Pertamina Gas Jakarta obtained a value of $54.87 \%$. So it can be concluded that the management of Wellness Center employees of PT. Pertamina Gas Jakarta is considered lacking. This program needs improvements in aspects of the procedures for recruiting trainers, and staff, improving the quantity and quality of facilities and infrastructure, the performance of staff and trainers, and socializing the services of the Wellness Center program.
\end{abstract}

Keywords: evaluation, management, wellness center, employees of PT. Pertamina Gas Jakarta.

\begin{abstract}
Abstrak. Penelitian ini bertujuan untuk mendapatkan informasi tentang manajemen Wellness Center pegawai PT. Pertamina Gas Jakarta. Penelitian evaluasi ini menggunakan metode penelitian campuran (Mix-Methode) dengan pendekatan model evaluasi Context, Input, Process, Product (CIPP). Pengumpulan data dilakukan dengan cara wawancara, observasi dan studi dokumentasi. Hasil penelitian menyimpulkan bahwa: (1). Komponen evaluasi yang terdapat pada tahapan context dinilai baik (68,15\%). (2). Komponen evaluasi yang terdapat pada tahapan imput dinilai cukup (58,76\%). (3). Komponen evaluasi yang terdapat pada tahapan process dinilai kurang $(55,17 \%)$. (4). Komponen evaluasi yang terdapat pada tahapan product dinilai sangat kurang $(37,14 \%)$. Secara keseluruhan hasil evaluasi manajemen Welness Center pegawai PT. Pertamina Gas Jakarta diperoleh nilai sebesar $54,87 \%$. Sehingga dapat disimpulkan bahwa manajemen Wellness Center pegawai PT. Pertamina Gas Jakarta dinilai kurang. Program ini perlu adanya perbaikan-perbaikan pada aspek tata cara perekrutan pelatih, dan staf, peningkatan kuantitas dan kualitas sarana dan prasarana, kinerja staf dan pelatih, dan sosialisasi layanan program Wellness Center.
\end{abstract}

Kata kunci: evaluasi, manajemen, wellness center, pegawai PT. Pertamina Gas Jakarta. 


\section{PENDAHULUAN}

Kesehatan merupakan salah satu kunci yang penting bagi aspek pendukung manusia untuk dapat melaksanakan kegiatannya sehari-hari. Salah satu usaha atau upaya untuk mendapatkan tubuh yang sehat lahir dan batin adalah dengan olahraga. Olahraga sangat berperan penting dalam menunjang kualitas produktifitas segala kegiatan manusia. Tingkat kesadaran untuk berolahraga banyak mulai disosialisasikan kepada sebagian besar masyarakat Indonesia.

Tingkat kesehatan dan kesejahteraan pegawai menjadi salah satu perhatian utama bagi perusahaan. Dalam lingkungan ketenagakerjaan, pekerja memiliki hak untuk memperoleh perlindungan atas keselamatan kerja dan kesehatan dalam perusahaan. Pemerintah melalui Undang-Undang Nomor 13 Tahun 2003 Tentang Ketenagakerjaan pasal 86 ayat (2).

Berbagai jenis upaya yang dapat dilakukan perusahaan dalam meningkatkan minat berolahraga pegawainya, seperti membangun beberapa fasilitas dan kegiatan olahraga untuk pegawainya. Salah satunya di tempat peneliti bekerja yaitu PT. Pertamina Gas Jakarta. Minat atau animo pegawai sangat sedikit untuk berolahraga di Wellnes Center ini. Pegawai yang rutin menggunakan fasilitas ini jumlahnya sangat jauh dari setengah total jumlah seluruh karyawan Pertagas Jakarta. Jumlah pegawai yang menikmati fasilitas ini dapat dilihat dari data pengunjung Wellness Center yang hadir. Hal ini yang menarik perhatian peneliti untuk melihat secara langsung tentang aspek-aspek esensial dalam evaluasi manajemen Wellness Center pegawai PT. Pertamina Gas Jakarta agar menjadi lebih baik.

Evaluasi merupakan salah satu bagian dari sistem manajemen yaitu perencanaan, organisasi, pelaksanaan, monitoring dan evaluasi. Tanpa evaluasi, maka tidak akan diketahui bagaimana kondisi objek evaluasi tersebut dalam rancangan, pelaksanaan serta hasilnya. Dalam bidang manajemen, evaluasi tidak lepas dari kegiatan ME (monitoring dan evaluasi) yang merupakan rangkaian dari kegiatan perencanaan dan pelaksanaan dari suatu program. Menurut Davidson.E Jane, hal-hal yang dapat dan bisa gunakan dengan sistematis evaluasi antara lain: Projects, programs, or organizations, Personnel or performance, Policies or strategies, Product or service, Processes or systems, Proposal, contract bids, or job applications (Jane, 2005:1)

Ada beberapa definisi evaluasi menurut beberapa ahli lainnya. Dalam buku evaluasi program pendidikan yang ditulis oleh Arikunto \& Jabbar (2009). Menuliskan pendapat Suchman memandang evaluasi sebagai sebuah proses menentukan hasil yang telah dicapai beberapa kegiatan yang direncanakan untuk mendukung tercapainya tujuan. Menurut Arikunto \& Jabbar (2009:2), "evaluasi adalah kegiatan untuk mengumpulkan informasi tentang bekerjanya sesuatu, yang selanjutnya informasi tersebut digunakan untuk menentukan alternatif yang tepat dalam mengambil sebuah keputusan". 
Tujuan evaluasi adalah mengumpulkan informasi untuk menentukan nilai dan manfaat objek evaluasi, mengontrol, memperbaiki, dan mengambil keputusan mengenai objek tersebut (Wirawan, 2012:9). Davidson.E Jane dalam bukunya yang berjudul Evaluation Methodology Basics: the nuts, and bolts of sound evaluation menyebutkan "what is (are) the main purpose(s) of the evaluation? i) to determine the overall quality or value of something; ii) to find areas for improvement; iii) both of the above" (Jane, 2005:13).

Evaluasi erat kaitannya dengan kebijakan atau program yang direncanakan atau ditetapkan, baik yang sedang berjalan maupun yang telah selesai dilaksanakan. Oleh karena itu munculah istilah evaluasi program. Evaluasi program yaitu "Metode sistematik untuk mengumpulkan, menganalisis, dan memakai informasi untuk menjawab pertanyaan dasar mengenai program. Evaluasi program dapat dikelompokkan menjadi evaluasi proses (process evaluation), evaluasi manfaat (outcome evaluation) dan evaluasi akibat (impact evaluation)" (Wirawan, 2012:17).

Menurut dua ahli evaluasi yaitu Cronbach dan Stufflebeam mengemukakan bahwa evaluasi program adalah upaya menyediakan informasi untuk disampaikan kepada pengambil keputusan (Arikunto \& Jabbar, 2009). Evaluasi program dapat diartikan sebagai suatu kegiatan penilaian apakah program yang diterapkan sudah berjalan sesuai yang diharapkan atau tidak.

Setelah mendapatkan hasil informasi dari evaluasi program, terdapat empat kemungkinan yang dapat lakukan pada program yang diteliti, yaitu:

1) Menghentikan program, program dihentikan apabila tidak ada manfaatnya atau program tersebut tidak sesuai dengan apa yang diharapkan.

2) Merevisi program, pada bagian-bagian tertentu tidak sesuai dengan harapan.

3) Melanjutkan program, program tersebut berjalan sesuai dengan harapan dan memiliki hasil bermanfaaat.

4) Menyebarluaskan program, melaksanakan program ditempat lain atau mengulangi program dilain waktu (Arikunto \& Jabbar, 2009:22).

Manajemen diartikan dengan bermacam-macam cara, tergantung pandangan, keyakinan dan pemahaman dari pembuat definisi. Menurut George R. Terry "management is a distinct process consisting of planning, organizing, actuating, and controlling performed to determine and accomplish stated objectives by the use of human being and other resources" (Hasibuan, 2014:2). Menurut Mary Parker Follet yang dikutip oleh Khaerul Umam (2012), manajemen adalah suatu seni untuk melaksanakan suatu pekerjaan melalui orang lain. Sedangkan menurut Malayu S.P Hasibuan (2014), manajemen adalah ilmu dan seni mengatur proses pemanfaatan sumber daya manusia dan sumber-sumber lainnya secara efektif dan efisien untuk mencapai suatu tujuan tertentu. 
Dalam menjalankan tugasnya, manajer menggunakan 6 unsur atau peralatan manajemen (tools of management) yang dikenal sebagai $6 \mathrm{M}$ yaitu:

1) Man (manusia/orang); yaitu tenaga kerja manusia, baik itu pimpinan maupun tenaga operasional.

2) Money (uang), uang yang dibutuhkan dalam mencapaian tujuan.

3) Method (metode), metode atau cara yang digunakan dalam pencapaian tujuan.

4) Materials (bahan-bahan), segala bentuk bahan yang digunakan dalam proses pencapaian tujuan yang diinginkan.

5) Macbine (mesin), alat-alat yang diperlukan dan dibutuhkan dalam mencapaian tujuan.

6) Market (pasar), sebagai tempat untuk menjual barang atau jasa yang dihasilkan (Hasibuan, 2014:20).

Fungsi-fungsi manajemen yang menjadi landasan manajemen dalam penelitian ini:

1. Perencanaan

"Perencanaan merupakan proses terpenting dari semua fungsi manajemen karena tanpa perencanaan fungsi-fungsi lainnya tak dapat berjalan" (Yunida, Sugiharto, \& Soenyoto, 2017:126). Tujuan dari perencanaan adalah untuk menentukan serangkaian tindakan yang diperlukan dalam pencapaian tujuan. Menurut Stoner yang dikutip oleh Khaerul Umam (2012), planning adalah proses menetapkan sasaran dan tindakan yang diperlukan untuk mencapai sasaran organisasi. Menurut Ridhotulla \& Jauhar (2015:1), kegiatan dalam perencanaan terdiri dari: (1). Menetapkan tujuan dan target bisnis. (2). Merumuskan strategi untuk mencapai tujuan dan target bisnis tersebut. (3). Menentukan sumber-sumber daya yang diperlukan. (4). Menetapkan standar/indikator keberhasilan dalam pencapaian tujuan dan target bisnis. Perencanaan manajemen Wellness Center ini akan dilihat berdasarkan kebijakan perusahaan dan strategi yang direncanakan

\section{Pengorganisasian}

Setelah menyusun perencanaan, tahap selanjutnya adalah pengorganisasian. Menurut Hasibuan (2014), pengorganisasian merupakan suatu proses penentuan, pengelompokan, dan pengaturan macam-macam aktivitas yang diperlukan untuk mencapai tujuan, menempatkan orang-orang pada setiap aktivitas ini, menyediakan alat-alat yang diperlukan, menetapkan wewenang yang secara relatif didelegasikan kepada setiap individu yang akan melakukan aktivitasaktivitas tersebut. Pengorganisasian dalam manajemen wellness center PT. Pertamina Gas Jakarta harus ditata dengan baik dan saling bekerja sama antar anggotanya demi tercapainya tujuan 
bersama. Dalam penelitian ini, pengorganisasian akan dilihat dari segi kompetensi pelatih dan staf, sarana dan prasarana serta pendanaan.

\section{Pelaksanaan}

Setelah melakukan tahap pengorganisasian, selanjutnya tahap pelaksaaan (actuating). Actuating disebut juga sebagai directing. Menurut Terry dalam Torang (2014), actuating adalah membuat semua anggota kelompok ingin mencapai tujuan secara sukarela dan sesuai dengan perencanaan manajerial dan upaya pengorganisasian. Pelaksanaan manajemen Wellness Center ini yang difokuskan adalah dengan melihat kinerja pelatih dan staf serta layanan program yang di tawarkan dan dijalankan.

\section{Pengawasan}

Pengawasan sering disebut juga sebagai pengendalian. Dalam terminologi bahasa Inggris, pengawasan atau pengendalian sering dinamakan sebagai controlling, evaluasting, appraising, dan correcting (Sule \& Saefullah, 2012). Arti dari semua istilah ini hampir sama yang tujuan dasarnya untuk memastikan agar apa yang telah direncanakan berjalan sebagaimana mestinya. Pengawasan atau pengendalian berhubungan erat dengan fungsi perencanaan dan keduanya saling mengisi karena: (1). Pengendalian harus lebih dahulu direncanakan. (2). Pengendalian baru dapat dilakukan jika ada rencana. (3). Pelaksanaan rencana akan baik, jika pengendalaian dilakukan dengan baik pula. (4). Tujuan baru dapat diketahui tercapai dengan baik atau tidak setelah pengendalian atau penilaian dilakukan (Hasibuan, 2014:214). Proses pengendalian dalam penelitian ini akan dilakukan pada tahapan akhir yang berupa produk dalam model penelitian evaluasi. Produk dalam model ini akan dilihat bagaimana tingkat kepuasan layanan dan realisasi jumlah pengunjung fasilitas.

Penelitian ini akan menggunakan model CIPP dengan empat sasaran evaluasi yaitu Context, Input, Process, dan Product. Menurut Wirawan (2012) menjelaskan komponen kunci model evaluasi CIPP sebagai berikut:

(1) Context evaluation, dalam evaluasi konteks ini berupaya untuk merincikan kebutuhan yang tidak terpenuhi, tujuan dari program atau kebijakan, dan target atau sasaran apa yang menjadi tujuan dari program atau kebijakan tersebut.

(2) Input evaluation, evaluasi masukan ini merumuskan apa yang menjadi kebutuhan dari program atau kebijakan yang direncanakan. Seperti menentukan sumber-sumber alternatif yang diambil, serta menentukan rencana atau strategi yang digunakan dalam mencapai tujuan.

(3) Process evaluation, evaluasi proses bertujuan untuk memeriksa apakah rencana proyek atau program yang telah berjalan sesuai dengan apa yang telah dirancanakan. 
(4) Product evaluation, dalam evaluasi produk ini untuk mengetahui akhir dari program atau kebijakan yang direncanakan. Yang hasilnya nanti menjadi dasar keputusan selanjutnya.

Model CIPP juga memiliki keunggulan dibandingkan dengan model lainnya. Salah satu yang menjadi keunggulan model CIPP adalah lebih komprehensif. Menurut (Darodjat dan Wahyudhiana M, 2015) model CIPP memiliki beberapa kelebihan antara lain: lebih komprehensif, karena objek evaluasi tidak hanya pada hasil semata tetapi juga mencakup konteks, masukan (imput), proses, maupun hasil. Menurut (Mahmudi, 2011). Keunggulan model CIPP memberikan suatu format evaluasi yang komprehensif pada setiap tahapan evaluasi tersebut di atas. Model evaluasi CIPP (Context-Input-Process-product) adalah kerangka kerja yang komprehensif untuk memandu evaluasi formatif dan sumatif dari sebuah, program, proyek, personel, produk, institusi, sistem, dan pelajaran. (Tiantong \& Tongchin, 2013)

\section{METODE}

Penelitian ini menggunakan pendekatan yang mengacu pada model CIPP dengan empat sasaran evaluasi (Context, Input, Process, dan Product). Evaluasi ini bertujuan mengumpulkan informasi tentang realisasi atau implementasi dari suatu kebijakan, CIPP (Contex, Input, Proses dan Produk) berlangsung dalam proses yang berkesinambungan, dan terjadi dalam suatu organisasi yang melibatkan sekelompok orang guna pengambilan keputusan (Agung Sunarno, 2016).

Metode penelitian yang digunakan dalam evaluasi metode penelitian ini menggunakan metode penelitian campuran (Mix-Methode). Menurut Cresswell dan Plano Clark yang dikutip oleh (Vebrianto, 2018) Rancangan penelitian metode campuran (mixed methods research design) adalah suatu prosedur untuk mengumpulkan, menganalisis, "dan mencampur" metode kuantitatif dan kualitatif dalam suatu penelitian atau serangkaian penelitian untuk memahami permasalahan penelitian. Menurut (Almalki, 2016) metode penelitian campuran merupakan pendekatan yang tepat untuk setiap penelitian yang dilaksanakan, penggunaannya akan menghasilkan manfaat yang positif, di mana penggunaan pendekatan yang berbeda memiliki potensi untuk memberikan informasi yang dalam dan luas yang tidak mungkin dilakukan dengan menggunakan pendekatan tunggal

Prosedur pengumpulan data melalui wawancara, observasi, dan dokumentasi. Pemeriksaan keabsahan data dilaksanakan melalui ketekunan pengamatan peneliti, triangulasi dan pemeriksaan rekan sejawat melalui diskusi. Analisis data penelitian dilakukan dengan prosedur sebagai berikut: 1) Reduksi data 2) Penyajian data dan 3) Penarikan kesimpulan. 


\section{TEMUAN}

1. Komponen Konteks Manajemen Wellness Center pegawai PT. Pertamina Gas Jakarta

a. Dasar Kebijakan Perusahaan Dalam Pengelolaan Manajemen Wellness Center pegawai PT. Pertamina Gas Jakarta

Komponen konteks evaluasi tentang dasar kebijakan perusahaan pada manajemen Wellness Center pegawai PT. Pertamina Gas Jakarta di kategorikan baik secara keseluruhan. Perolehan data skor rata-rata jawaban responden sebesar 72,78\% menunjukkan bahwa dasar kebijakan Wellness Center pegawai pada PT. Pertamina Gas Jakarta termasuk ke dalam kategori baik $(66 \%-79 \%)$.

b. Strategi Perencanaan Dari Manajemen Wellness Center pegawai PT. Pertamina Gas Jakarta

Komponen konteks berkaitan dengan strategi perencanaan manajemen Wellness Center pegawai PT. Pertamina Gas Jakarta diperoleh nilai rata-rata sebesar 64,84\%. Secara keseluruhan, dengan skor rata-rata $64,84 \%$ menunjukkan bahwa strategi perencanaan manajemen Wellness Center pegawai PT. Pertamina Gas Jakarta termasuk ke dalam kategori cukup (56\% - 65\%).

\section{Komponen Input Manajemen Wellness Center pegawai PT. Pertamina Gas Jakarta}

a. Kompetensi Pelatih pada Manajemen Wellness Center pegawai PT. Pertamina Gas Jakarta

Komponen input kompetensi pelatih yang dievaluasi diperoleh nilai rata-rata sebesar 56,65\%. Secara keseluruhan, dengan skor rata-rata 56,65\% menunjukkan bahwa kompetensi pelatih dalam manajemen Wellness Center pegawai PT. Pertamina Gas Jakarta termasuk ke dalam kategori cukup $(56 \%-65 \%)$.

\section{b. Kompetensi Staf Manajemen Wellness Center pegawai PT. Pertamina Gas Jakarta}

Kompetensi staf pada manajemen Wellness Center pegawai PT. Pertamina Gas Jakarta diperoleh nilai rata-rata sebesar 53,70\%. Secara keseluruhan, dengan skor rata-rata 53,70\% menunjukkan bahwa kompetensi staf dalam manajemen Wellness Center PT. Pertamina Gas Jakarta termasuk kategori kurang (40\% - 55\%).

\section{c. Kualitas Sarana Dan Prasarana Manajemen Wellness Center pegawai PT. Pertamina Gas Jakarta}

Komponen input sarana dan prasarana manajemen Wellness Center pegawai PT. Pertamina Gas Jakarta diperoleh nilai 63,40\%. Secara keseluruhan, dengan skor rata-rata sebesar 63,40\% menunjukkan bahwa kualitas sarana dan prasarana dalam manajemen Wellness Center pegawai PT. Pertamina Gas Jakarta termasuk ke dalam kategori kategori cukup (56\% - 65\%). 


\section{d. Pendanaan Manajemen Wellness Center pegawai PT. Pertamina Gas Jakarta}

Komponen input Pendanaan pada manajemen Wellness Center pegawai PT. Pertamina Gas Jakarta diperoleh nilai 71,44\%. Secara keseluruhan, dengan skor rata-rata sebesar $71,44 \%$ menunjukkan bahwa kualitas sarana dan prasarana dalam manajemen Wellness Center pegawai PT. Pertamina Gas Jakarta termasuk ke dalam kategori baik (66\% - 79\%).

\section{Komponen Proses Manajemen Wellness Center pegawai PT. Pertamina Gas Jakarta}

\section{a. Kinerja Pelatih Pada Wellness Center pegawai PT. Pertamina Gas Jakarta}

Komponen proses evaluasi kinerja pelatih Wellness Center pegawai PT. Pertamina Gas Jakarta diperoleh nilai sebesar 56,85\%. Secara keseluruhan, dengan skor rata-rata sebesar 56,85\% menunjukkan bahwa kinerja Pelatih Wellness Center pegawai PT. Pertamina Gas Jakarta termasuk ke dalam kategori cukup (56\% - 65\%).

\section{b. Kinerja Staf Pada Wellness Center pegawai PT. Pertamina Gas Jakarta}

Komponen proses evaluasi kinerja staf Wellness Center pegawai PT. Pertamina Gas Jakarta diperoleh nilai 54,81\%. Secara keseluruhan, dengan skor rata-rata sebesar 54,81\% menunjukkan bahwa kinerja staf Wellness Center pegawai PT. Pertamina Gas Jakarta termasuk ke dalam kategori kurang $(40 \%-55 \%)$.

\section{c. Pelaksanaan Layanan Program Pada Wellness Center pegawai PT. Pertamina Gas Jakarta}

Komponen proses evaluasi pelaksanaan layanan program pada Wellness Center PT. Pertamina Gas Jakarta diperoleh nilai 53,19\%. Secara keseluruhan, dengan skor rata-rata 53,19\% menunjukkan bahwa pelaksanaan layanan program Wellness Center pegawai PT. Pertamina Gas Jakarta termasuk ke dalam kategori kurang (40\% - 55\%).

\section{Komponen Produk Manajemen Wellness Center pegawai PT. Pertamina Gas Jakarta}

\section{a. Realisasi Pengunjung Pada Wellness Center pegawai PT. Pertamina Gas Jakarta}

Realisasi pengunjung di Wellness Center pegawai PT. Pertamina Gas Jakarta di kategorikan sangat kurang secara keseluruhan. Perolehan data skor rata-rata realiasi pegunjung sebesar 23,75\% menunjukkan bahwa realisasi pengunjung Wellness Center pegawai pada PT. Pertamina Gas Jakarta termasuk ke dalam kategori sangat kurang $(\leq-40 \%)$.

b. Tingkat Kepuasan Pengunjung Terhadap Layanan Manajemen Wellness Center pegawai PT. Pertamina Gas Jakarta

Tingkat kepuasaan layanan program pada Wellness Center PT. Pertamina Gas Jakarta diperoleh nilai 51,08\%. Secara keseluruhan, dengan skor rata-rata 51,08\% menunjukkan bahwa 
Tingkat kepuasaan terhadap pelaksanaan layanan program Wellness Center pegawai PT. Pertamina Gas Jakarta termasuk ke dalam kategori kurang (40\% - 55\%).

\section{DISKUSI}

1. Komponen Konteks Manajemen Wellness Center pegawai PT. Pertamina Gas Jakarta

a. Dasar Kebijakan Perusahaan Dalam Pengelolaan Manajemen Wellness Center pegawai PT. Pertamina Gas Jakarta

Berdasarkan temuan di lapangan terkait dengan dasar kebijakan adalah belum adanya kebijakan khusus secara tertulis masih bersifat himbauan tentang program Wellness Center. Akibat tidak adanya kebijakan secara tertulis tentang pengeloaan Wellness Center secara mandiri dan professional secara tidak langsung visi, misi, strategi perencanaan di Wellness Center tidak ada. Pengelolaan nya masih berjalan tidak beraturan dan tidak tersusun secara jelas. Karena Wellnes Center sendiri masih sebuah fasilitas yang disediakan kantor untuk meningkatkan mutu kesehatan para pegawainya. Wellness Center sendiri merupakan bagian dari program layanan kesehatan bagi pegawai PT. Pertamina Gas yang dikelola Badan Olahraga dan Seni (Bapor) PT. Pertamina Gas. Artinya pengelolaan Wellness Center belum sepenuhnya dikelola secara professional karena masih dibawah kordinasi Bapor dalam pengelolaannya. Wellness Center sebagai salah wadah dalam upaya pengelolaan kesehatan keluarga pekerja di PT. Pertamina Gas yang meliputi peningkatan kesehatan (promotif), sosialisasi pencegahan (preventif), pengobatan (kuratif), pemulihan kesehatan (rehabilitatif) hingga perlindungan (protektif).(Gas, 2017).

Hal di atas sesuai dengan hasil penelitian (Cori, Paramita, \& Wijayanto, 2012), kesehatan kerja adalah spesialisasi dari ilmu-ilmu kesehatan atau kedokteran beserta prakteknya yang bertujuan agar pekerja atau masyarakat pekerja memperoleh derajat kesehatan setinggitingginya baik fisik maupun mental dan sosial dengan usaha preventif dan kuratif terhadap penyakitpenyakit gangguan kesehatan yang diakibatkan faktor-faktor pekerjaaan dan lingkungan kerja serta terhadap penyakit umum. Sedangkan menurut (Kusuma \& Efranto, 2011), program kesehatan kerja mempunyai pengaruh negatif dan signifikan terhadap faktor penyakit akibat kerja dengan $\mathrm{P}=-10,89$ dan $|10,89|>|1,96|$ (two-tailed) dengan nilai koefisien sebesar -0,83, koefisien ini menunjukkan bahwa apabila semakin baik pelaksanaan program kesehatan kerja maka kejadian penyakit/sakit akibat kerja akan semakin kecil dan sebaliknya.

Kebijakan PT. Pertamina Gas Jakarta dengan memberikan fasiltas dan layanan Wellness Center bagi pegawai sejalan dengan kebijakan Pemerintah yakni memberikan hak bagi pegawai untuk memperoleh perlindungan atas keselamatan kerja dan kesehatan dalam perusahaan. Pemerintah melalui Undang-Undang Nomor 13 Tahun 2003 Tentang Ketenagakerjaan pasal 86 
ayat (2) yang berbunyi "Untuk melindungi keselamatan pekerja/buruh guna mewujudkan produktivitas kerja yang optimal diselenggarakan upaya keselamatan dan kesehatan kerja."

Disamping Undang-Undang Nomor 13 Tahun 2003 Tentang Ketenagakerjaan, beberapa hasil penelitian menjelaskan bahwa kebijakan kesehatan yang di terapkan oleh perusahaan memiliki pengaruh dalam meningkatkan produktivitas dan kinerja pegawai. Menurut (Wahyuni, Suyadi, \& Hartanto, 2018) menjelaskan bahwa: Keselamatan dan kesehatan kerja termasuk salah satu program pemeliharaan yang ada di perusahaan. Pelaksanaan program keselamatan dan kesehatan kerja bagi karyawan sangatlah penting karena bertujuan untuk menciptakan sistem keselamatan dan kesatuan kerja yang nantinya dapat meningkatkan produktivitas kerja karyawan. Hasil penelitian ini menunjukkan bahwa "keselamatan dan kesehatan kerja (K3) berpengaruh signifikan terhadap produktivitas kerja karyawan pada PT. Kutai Timber Indonesia".

\section{b. Strategi Perencanaan Dari Manajemen Wellness Center pegawai PT. Pertamina Gas Jakarta}

Strategi perencanaan yang belum terpenuhi pada manajemen Wellness Center pegawai PT. Pertamina Gas Jakarta adalah tidak adanya pedoman penyelenggaraan manajemen Wellness Center PT. Pertamina Gas Jakarta. Pedoman disini hendaknya harus ada karena ini merupakan pedoman dan rambu-rambu pelaksanaan manajemen Wellness Center PT. Pertamina Gas Jakarta. Tidak adanya pedoman berupa petunjuk ini berdampak pada proses rekrutmen pelatih dan staf. Proses perekrutan pelatih dan staf hanya melalui tahap wawancara, terutama pada perekrutan staf. Proses perekrutan pelatih dan staf belum sepenuhnya ditinjau dari aspek akademik dan keterampilan. Aspek akademik belum adanya standar pendidikan sesuai dengan kebutuhan untuk ditempatkan di Wellness Center. Aspek keterampilan dalam proses perekrutan tidak ditemukannya sistem rekrutmen berdasarkan kemampuan yang sudah diakui dalam bentuk sertifikat keterampilan. Perekrutan pelatih di Wellness Center masih mengutamakan aspek pengalaman, sedangkan perekrutan staf di Wellness Center masih ditemukannya unsur nepotisme (kekerabatan).

Hasil evaluasi strategi perancanaan pada manajemen Wellness Center pegawai PT. Pertamina Gas Jakarta sudah berjalan dengan cukup baik. Strategi perencanaan merupakan modal penting dalam memulia sebuah program. Hasil evaluasi strategi perencanaan manajemen $W$ ellness Center pegawai PT. Pertamina Gas Jakarta masih perlu ditingkatkan lagi untuk program manajemen Wellness Center pegawai PT. Pertamina Gas Jakarta mendatang. Menurut Ridhotulla \& Jauhar (2015:1), kegiatan dalam perencanaan terdiri dari: (1). Menetapkan tujuan dan target bisnis. (2). Merumuskan strategi untuk mencapai tujuan dan target bisnis tersebut. (3). Menentukan sumber-sumber daya yang diperlukan. (4). Menetapkan standar/indikator keberhasilan dalam pencapaian tujuan dan target bisnis. 
Hasil evaluasi komponen konteks secara keseluruhan yang meliputi dasar kebijakan perusahaan dan strategi manajemen Wellness Center pegawai PT. Pertamina Gas Jakarta diperoleh nilai rata-rata 68,15\%. Secara keseluruhan, dengan skor rata-rata sebesar 68,15\% menunjukkan bahwa evaluasi komponen konteks manajemen Wellness Center pegawai PT. Pertamina Gas Jakarta termasuk ke dalam dalam kategori baik (66\% - 79\%). Hasil penelitian konteks ini sesuai dengan hasil penelitian (Firdaus, 2011) yang menjelaskan bahwa konteks pembinaan olahraga yang ada, dipengaruhi oleh situasi atau latar belakang yang mempengaruhi perencanaan program pembinaan, terutama untuk penyebaran informasi dan sumber daya manusia yang ada. Konteks manajemen Wellness Center pegawai PT. Pertamina Gas Jakarta menjadi dasar dalam pencapaian target program manajemen Wellness Center ini yaitu: (1). Meningkatnya kesadaran pentingnya budaya hidup sehat bagi seluruh karyawan.(2) Tingkat kebugaran yang prima dan status gizi yang optimal seluruh karyawan. (3). Peningkatan produktifitas karyawan (Rumah Sakit Pertamina Jaya, 2015:3).

\section{Komponen Input Manajemen Wellness Center pegawai PT. Pertamina Gas Jakarta}

\section{a. Kompetensi Pelatih pada Manajemen Wellness Center pegawai PT. Pertamina Gas Jakarta}

Kompetensi pelatih berdasarkan pada sertifikat akademik, yang dimiliki oleh pelatih di Wellness Center bukan berasal dari lulusan keolahragaan. Bahkan berdaasarkan telaah di lapangan ada salah satu pelatih di $W$ ellness Center yang memiliki sertifikat formal saya D1 komputer akutansi. Kelemahan tidak memiliki sertifikat formal di bidang keolahragaan mereka meningkatkan dan mengembangkan kemampuan diri melalui beberapa seminar, pelatihan dan kursus tentang fitness. Sehingga dari sisi akademik tidak memiliki sertifikat keolahragaan tetapi memiliki sertifikat keterampilan olahraga. Aspek pengetahuan tentang fitness dan pengalaman bekerja seorang pelatih menjadi komponen utama dalam proses rekrutmen pelatih. Kompetensi pelatih yang bekerja di Wellness Center PT. Pertamina Gas Jakarta memiliki pengalaman bekerja di fitness hampir 10 tahun lebih. Setiap tahunnya pasti ada hal yang baru untuk dipelajari di dunia fitness, apalagi setiap trainer mempunyai spesifikasi tersendiri. Oleh karena itu dari sisi peningkatan pengetahuan mereka masih aktif mengikuti kegiatan-kegiatan dalam menunjang profesi pelatih seperti seminar fitness, les yoga, kursus personal trainer, dan lain-lain.

Berdasarkan hasil penelitian di atas kompetensi pelatih merupakan hal yang penting karena menurut kompetensi merupakan suatu kemampuan untuk melaksanakan atau melakukan suatu pekerjaan atau tugas yang dilandasi atas keterampilan dan pengetahuan serta didukung oleh sikap kerja yang dituntut oleh pekerjaan tersebut. Wibowo (2014). Sedangkan kompetensi Pelatih olahraga dalam manajemen fitness. Menurut .(Pelana, 2017) dijelaskan bahwa salah satu syarat 
penting yang harus dipenuhi dalam pembinaan untuk keperluan pembangunan di bidang olahraga adalah terdapatnya sumber daya manusia yang berkualitas dan berkompetensi untuk menjadi pelaku IPTEK olahraga.

\section{b. Kompetensi Staf Manajemen Wellness Center pegawai PT. Pertamina Gas Jakarta}

Kompetensi staf berdasarkan pada sertifikat akademik, sebagian besar yang dimiliki Wellness Center merupakan lulusan SMA. Hanya beberapa orang staf yang lulusan strata 1. Dari aspek akademik belum menjadi perhatian pihak manajemen dalam proses rekrutmen staf. Aspek keterampilan mengoperasikan komputer dan dan pengalaman kerja menjadi komponen utama dalam proses rekrutmen staf. Proses rekrutmen staf di Wellness Center PT. Pertamina Gas Jakarta masih ditemukan perekrutan yang tidak sesuai mekanisme yang berlaku. Terdapat beberapa staf yang bekerja di Wellness Center karena faktor kekeluargaan.

Berdaasarkan hasil kompetensi staf di atas dijelaskan bahwa staf yang dimiliki Wellness Center masih belum memiliki karakteristik kompetensi yang ideal dalam manajemen Wellness Center. Menurut (Wibowo, 2014) terdapat lima tipe karakteristik kompetensi yaitu: (1). Motif adalah sesuatu yang secara konsisten dipikirkan atau diinginkan orang yang menyebabkan tindakan. (2). Sifat adalah karakteristik fisik dan respon yang konsisten terhadap situasi atau informasi. (3). Konsep diri adalah sikap, nilai-nilai, atau citra diri seseorang. (4). Pengetahuan adalah informasi yang dimiliki orang dalam bidang spesifik.(5). Keterampilan adalah kemampuan mengerjakan tugas fisik atau mental tertentu

\section{c. Kualitas Sarana Dan Prasarana Manajemen Wellness Center pegawai PT. Pertamina Gas Jakarta}

Kualitas sarana dan prasarana manajemen Wellness Center pegawai PT. Pertamina Gas Jakarta masuk ke dalam kategori cukup. Masih minimnya minat yang berolahraga dan pegawai yang datang di Wellness Center di dominasi oleh bapak-bapak dan ibu-ibu sehingga kebutuhan belum lebih spesifik. Karena sebagian alat yang dipakai di Wellness Center masih yang sederhana. Kedepannya harapan dari manajemen akan menambah sarana yang lebih canggih agar menarik pegawai yang datang disamping berolahraga juga bertujuan membentuk badan. Kualitas prasarana yang menjadi catatan penting dari evaluasi ini. Letak gedung fitness Wellness Center yang berada di basement menjadikan tempat ini kurang nyaman. Disamping kondisi tempat yang kecil sehingga daya tamping terbatas juga kualitas sirkulasi udara dan pencahayaan yang minim. Catatan dari hasil evaluasi lainnya adalah dari aspek kuantitas, masih terdapat beberapa alat yang kurang seperti dumbbell, barbell, loker dan beberapa alat pendukung kebersihan. Kekurangan ini diakibatkan 
dari penyediaan alat yang jumlahnya sedikit juga dikarenakan belum adanya proses pergantian alat-alat yang rusak dari pihak koperasi.

Berdasarkan hasil penelitian di atas, beberapa hasil penelitian membuktikan bahwa sarana dan prasarana sangat penting dalam pembinaan olahraga. Jika sarana dan prasarana kurang maka secara langsung kan menghambat manajemen pembinaan olahraga itu sendiri. Menurut (Haryadi, Pratidina, \& Seran, 2016) faktor penghambat manajemen pembinaan adalah Kurangnya Sarana dan prasarana dan kelengkapan Olahraga yang tercukupi salah satu upaya untuk mengatasi masalah hambatan dan faktor dalam pembinaan adalah dengan tersediannya sarana, prasarana dan kelengkapan Olahraga yang tercukupi. Hasil penelitian (Busyairi, Ode, \& Safar, 2014) menjelaskan bahwa kesehatan kerja (pemeriksaan kesehatan, jam istirahat, ergonomi) yang diukur dari produktivitas kerja, memiliki kontribusi yang positif dan signifikan terhadap tinggi rendahnya produktivitas kerja sebesar 21,8\%. Jadi dengan semakin lengkapnya fasilitas dan perhatian yang serius akan kesehatan kerja di PT. XYZ maka akan semakin mempengaruhi produktivitas kerja dari karyawan.

Disamping sarana dan prasarana yang tercukupi, sarana dan prasarana olahraga harus memiliki standar yang ada untuk kegiatan keolahragaan. Hal ini sesuai dengan Peraturan Pemerintah RI No. 16 Tahun 2007 tentang penyelenggaraan olahraga, pasal 89 ayat 2 yang menyebutkan: (1). Ruang dan tempat berolahraga yang sesuai dengan persyaratan teknis cabang olahraga; (2). Lingkungan yang terbebas dari polusi air, udara dan suara; (3). Keselamatan yang sesuai dengan persyaratan keselamatan bangunan; (4). Keamanan yang dinyatakan dengan terpenuhinya persyaratan sistem pengamanan. (5). Kesehatan yang dinyatakan dengan tersedianya perlengkapan medik dan kebersihan (Presiden Republik Indonesia, 2007).

\section{d. Pendanaan Manajemen Wellness Center pegawai PT. Pertamina Gas Jakarta}

Hasil evaluasi dari aspek pendanaan secara keseluruhan sudah baik, karena sisitem pendanaan yang sudah teralokasi setiap tahunnya. Alokasi anggaran dianggarkan dalam pos kesehatan. Anggaran dikelola oleh koperasi baik untuk Wellens Center, dana kesehatan, gaji pelatih, gaji staf dan lain-lain. Catatan dari hasil evaluasi ini adalah ketika adanya alat yang rusak proses penanganannya lama karena harus melalui proses permohonan dan persetujuan pihak koperasi.

Dalam pendanaan kegiatan olahraga beberpa hal yang harus dipertimbangkan diantaranya adalah: (1). Bagaimana memperoleh dana untuk membiayai. (2). Bagaimana memperoleh dana tersebut sehingga tujuan perusahaan tercapai. (3). Bagaimana perusahaan mengelola asset yang dimiliki secara efisien dan efektif (Kasmir, 2010:6). Disamping pos pendapatan dan penglolaan seperti yang dimaksud di atas, pendaanaan juga merupakan sebuah fundamental kebershasilan 
suatu program. Hal ini dijelaskan Nanang Fattah yang dikutip (Wahidah, 2013) dijelaskan bahwa, penganggaran merupakan satu langkah perencanaan dan sebagai instrumen perencanaan yang fundamental. Penganggaran sebagai suatu rencana operasi dari suatu kegiatan atau proyek yang mengandung perincian pengeluaran biaya untuk periode tertentu.

Hasil evaluasi input manajemen Wellness Center pegawai PT. Pertamina Gas Jakarta secara keseluruhan yang meliputi: kompetensi pelatih, kompetensi staf, dan kualitas sarana dan prasarana serta pendanaan diperoleh nilai rata-rata sebesar 58,76\%. Secara keseluruhan, dengan skor ratarata sebesar 58,76\% menunjukkan bahwa evaluasi input manajemen Wellness Center pegawai PT. Pertamina Gas Jakarta termasuk ke dalam kategori cukup (56\% - 65\%). Maka dapat disimpulkan bahwa komponen evaluasi yang terdapat pada tahapan input ini dinilai cukup sesuai dengan pelaksanaan manajemen Wellness Center pegawai PT. Pertamina Gas Jakarta.

Hal ini sesuai dengan pendapat (Wirawan, 2012), menjelaskan bahwa: Evaluasi Masukan untuk mencari jawaban atas pertanyaan: Apa yang harus dilakukan? Evaluasi ini mengidentifikasi dan problem, aset, dan peluang untuk membantu pengambil keputusan mengidentifikasikan tujuan, prioritas-prioritas dan membantu kelompok-kelompok lebih luas pemakai untuk menilai tujuan, prioritas, dan manfaat-manfaat dari program, menilai pendekatan alternatif, rencana tindakan, rencana staff dan anggaran untuk feasibilitas dan potensi cost effectiveness untuk memenuhi kebutuhan dan tujuan yang ditargetkan.

\section{Komponen Proses Manajemen Wellness Center pegawai PT. Pertamina Gas Jakarta}

\section{a. Kinerja Pelatih Pada Wellness Center pegawai PT. Pertamina Gas Jakarta}

Pelatih Wellness Center sebagian besar sudah professional, karena sebelumnya sudah memiliki pengalaman bekerja di tempat fitness. Disamping memberikan program latihan yang baik dan benar, pelatih juga memberikan penjelasan terkait dengan asupan dan pola makan. Agar proses latihan memperoleh hasil yang maksimal. Berdasarkan hasil evaluasi, masih terdapat Pelatih Wellness Center yang masih belum mampu menyesuaikan kemampuan pengunjung yang datang. Ada beberapa pelatih yang memaksakan program yang ideal tanpa memperhatikan karakter pengunjung. Wellness Center merupakan sarana bagi para pegawai PT. Pertamina Gas dalam menjaga kebugaran dan kesehatan, tentunya beberapa pengunjung yang datang belum sepenuhnya memiliki minat untuk berolahraga. Karena masih ditemukan pengunjung yang datang karena ajakan teman. Oleh karena itu kinerja pelatih dituntut untuk menyesuaikan beberapa pengunjung yang masuk kategori pemula dan pelatih harus bisa memotivasi pengunjung agar terus berolahraga.

Berdasarkan hasil penelitian di atas kinerja Pelatih Wellness Center, masih perlu ditingkatkan lagi. Karena dalam memberikan pelayanan kepada pengunjung fitness seorang pelatih harus 
memiliki 5 dimensi pelayanan yaitu yaitu, reliability (kehandalan), responsiveness (ketanggapan), tangibles (bukti fisik), assurance (jaminan), dan empatby (empati). Jika telah memenuhi unsur lima dimensi ini, dapat dipastikan kinerja pelatih akan lebih baik. berdasarkan penelitian (Eric Soebari, 2016), kompetensi orientasi pelayanan personal trainer Atlas Sports Club Surabaya memenuhi standar 5 dimensi pelayanan, yang dimana semua personal trainer Atlas Sports Club berkompetensi karena sudah memiliki sertifikat personal trainer tingkat nasional.

Hasil penelitian lainnya menjelaskan bahwa persepsi atau kinerja pada keseluruhan mengenai program yang diberikan personal trainer pada member dengan dimensi dimensi Tangibles (Bukti Langsung), Reliability (Kehandalan), Responsiveness (Daya Tanggap), dimensi Assurance (Jaminan) dan dimensi Empathy (Empati) memiliki kinerja sangat memuaskan dengan rata-rata total persepsi atau kinerja sebesar 92.84\% melalui bentuk-bentuk program di celebrity fitness yaitu: Better Body Shape, Better Muscle Strengst, Better Athletic Performance, Better Healt And Fitness.(Handoko Dwi Purnomo, 2017).

\section{b. Kinerja Staf Pada Wellness Center pegawai PT. Pertamina Gas Jakarta}

Berdasarkan hasil evaluasi kinerja staf Wellness Center masih terdapat beberapa kekurangan. Staf yang ada Wellness Center memiliki pekerjaan double job. Staf tidak hanya bekerja di Wellness Center tetapi diperbantukan juga di koperasi sehingga pekerjaan di Wellness Center menjadi kurang maksimal. Oleh karena itu staf memiliki beban pekerjaan yang lebih disamping akibat double job, faktor yang mengakibatkan kinerja staf kurang yaitu belum adanya pembagian job desk yang tersusun dengan baik. Harapan kedepannya adanya penambahan dan pembagian staf sehingga ada yang khusus melayani di koperasi dan di Wellness Center. Catatan terkait dengan kinerja staf yang perlu dilakukan perbaikan adalah kedisiplinan staf dalam bekerja. Masih sering ditemukan beberapa staf yang terlambat masuk bekerja, bahkan lebih dulu pengunjung yang datang. Hasil evaluasi lainnya adalah staf belum mampu memberikan informasi program yang ada di $W$ ellness Center, sehingga pegawai hanya mengetahui sebagian program yang ada di Wellness Center.

Berdasarkan hasil kinerja staf $W$ ellness Center, salah satu faktor penyebab kurangnya kinerja Menurut Simanjuntak (2005) bahwa kinerja setiap individu dipengaruhi oleh banyak faktor yang dapat bagi menjadi 3 kelompok, yaitu: (1). Kompetensi individu, merupakan kemampuan dan keterampilan melakukan kerja yang dipengaruhi oleh kebugaran fisik dan kesehatan jiwa, pendidikan, akumulasi pelatihan, pengalaman kerja, motivasi dan etos kerja. (2). Dukungan organisasi, kinerja setiap orang juga tergantung pada dukungan organisasi dalam pengorganisasian, penyediaan sarana dan prasarana kerja, pemilihan teknologi, kenyamanan lingkungan kerja, serta kondisi dan syarat kerja. (3). Dukungan manajemen, kinerja juga sangat 
tergantung pada kemampuan manajerial para manajemen atau pemimpin, baik dalam sistem kerja dan hubungan industrial yang aman dan harmonis, maupun dengan mengembangkan kompetensi pekerja, demikian juga dengan menumbuhkan motivasi dan mobilitas seluruh karyawan untuk bekerja secara optimal.

Dalam rangka meningkatkan kinerja staf, hendaknya manajemen melaksanakan pendidikan dan pelatihan bagi staf Wellness Center. Hal ini sesuai dengan pendapat (Chaddha, 2016) yang menjelaskan bahwa: Kualitas karyawan dan pengembangan mereka melalui pelatihan dan pendidikan adalah faktor utama dalam menentukan profitabilitas jangka panjang dari setiap perusahaan. Pelatihan dianggap sebagai komponen penting untuk pengembangan kompetensi profesional lebih lanjut. Kegiatan pelatihan yang dirancang dengan baik untuk karyawan baru dan pelatihan berkelanjutan untuk karyawan saat ini membantu mereka menyesuaikan diri dengan persyaratan pekerjaan yang berubah dengan cepat.

Kegiatan pendidikan dan pelatihan salah satu nya meningkatkan Perfromance Service Quality (SERVPERF). Menurut (Lukito \& Brahmana, 2007) Perfromance Service Quality (SERVPERF) memiliki pengaruh terhadap Attitude hal ini dikarenakan performa dan pelayan sebuah perusahaan baik dalam menjual produk berupa barang atau jasa diharuskan untuk memberikan performa layanan agar tetap memberikan pengaruh positif terhadap sikap dari konsumennya, terutama bagi fitness center yang menawarkan produk berupa jasa. Hasil penelitian ini menunjukan bahwa Perfromance Service Quality memberikan pengaruh positif dan signifikan terhadap Workout Motives.

\section{c. Pelaksanaan Layanan Program Pada Wellness Center pegawai PT. Pertamina Gas Jakarta}

Berdasarkan 8 program yang ada (Aerobik, Boddy jump, Yoga, Weight Training, Fisioteraphy, layanan nutrisi dan gizi, serta konsultasi dengan dokter olahraga), program yang berjalan dengan baik adalah aerobic, boddy jump dan weight training. Beberapa program seperti Yoga, Fisioteraphy, layanan nutrisi dan gizi, serta konsultasi dengan dokter olahraga belum berjalan di Wellness Center. Beberapa faktor yang menyebabkan program tidak berjalan adalah kurangnya sosialiasi ke beberapa divisi pegawai PT. Pertamina Gas Jakarta, sehingga banyak pegawai yang belum mengetahui informasi layanan program yang disediakan oleh perusahaan. Faktor lainnya adalah waktu pelaksanaan program yang belum terjadwal dengan baik, sehingga pegawai PT. Pertamina Gas Jakarta belum mampu menyesuaikan antara jam bekerja dengan kegiatan olahraga.

Berdasarkan hasil evaluasi proses secara keseluruhan yang meliputi: kinerja pelatih, kinerja staf dan pelaksanaan layanan program diperoleh nilai rata-rata sebesar 55,17\%. Secara keseluruhan, dengan skor rata-rata sebesar 55,17\% menunjukkan bahwa evaluasi proses 
manajemen Wellness Center pegawai PT. Pertamina Gas Jakarta termasuk ke dalam kategori kurang $(40 \%-55 \%)$. Adanya beberapa indikator yang belum berjalan pada evaluasi konteks dan evaluasi input tentunya berpengaruh terhadap hasil evaluasi proses. Beberapa faktor belum berjalan yang ikut berpengaruh terhadap hasil proses adalah:

a) Evaluasi konteks: Belum ada kebijakan secara tertulis dalam mendukung Wellness Center, karena masih bersifat himbauan. Proses rekrutmen pelatih dan staf belum memperhatikan kemampuan dari segi akadmeik.

b) Evaluasi input: (1). belum ada pedoman penyelenggaraan pelaksanaan manajeman Wellness Center (2). Kuantitas dan kualitas sarana dan prasarana perlu diperbaiki lagi. (3). Koordinasi antar divisi dalam hal pendanaaan kekurangan sarana.

Berdasarkan hal di atas ada beberapa pelaksanaan rencana yang belum berjalan, sehingga berpengaruh terhadap program. Menurut (Stufelbeam \& Chris LCoryn, 2014) menjelaskan bahwa evaluasi proses menilai pelaksanaan rencana untuk membantu dalam melakukan kegiatan, kemudian menginterpretasikan hasil. Beberapa penelitian terdahulu menjelaskan bahwa kualitas layanan program sangat penting dan memberikan pengaruh untuk keberhasilan sebuah program khususnya tentang kepuasan members Wellness Center. Menurut (Aris, Irnanda; Utama, 2015) kualitas layanan secara signifikan mempengaruhi kepuasan pelanggan Helios Fitness Metro Indah Mall. Sedangkan, berdasarkan koefisien determinasi menunjukkan bahwa kualitas layanan mempengaruhi kepuasan pelanggan sebesar 68\%.

\section{Komponen Produk Manajemen Wellness Center pegawai PT. Pertamina Gas Jakarta}

\section{a. Realisasi Pengunjung Pada Wellness Center pegawai PT. Pertamina Gas Jakarta}

Realisasi pengunjung belum sesuai target, kurang dari 30\% dari jumlah karyawan yang ada sekitar 180 orang yang sudah menggunakan fasilitas Wellnes Cente. Dominannya para pegawai Wellnes Center memilih untuk berolahraga di pagi hari sebelum jam kerja. Setelah jam kerja mereka memilih untuk segera pulang ke rumah disaat jam pulang kantor. Sedangkan pegawai yang datang pada saat jam makan siang ke Wellnes Center merupakan pegawai yang benar-benar minat untuk olahraga. Bahkan berdasarkan data pengnujung, pengunjung yang datang hanya orang-orang tertentu saja yang memang sudah rutin menggunakan fasilitas Wellnes Center. Pengunjung yang berolahraga di Wellnes Center didominasi oleh non pegawai PT. Pertaamina Gas. Hal ini mengakibatkan pemakaian Wellnes Center cendrung digunakan untuk fasilitas olahraga masyarakat umum, hal ini tentunya harus menjadi perhatian pihak manajemen dalam pengelolaan Wellnes Center ke dapan. Belum adanya pedoman penyelanggaraan manajemen Wellnes Center akhirnya timbul beberapa asumsi jika Wellnes Center merupakan tempat olahraga untuk umum. 
Dalam rangka meningkat realisasi pengunjung perlu adaya terobosan dalam bentuk sosialisasi dan meningkatkan layanan. Hal ini bertujuan untuk lebih mengenalkan program Wellnes Center bagi para pegawai PT. Pertamina Gas. Berdasarkan hasil penelitian yang dilakukan oleh (Tae Kim, Bae, Kim, \& Lee, 2016) penelitian dengan judul The Servicescape in the Fitness Center: Measuring Fitness Center's Services. Hasil penelitian menyimpulkan bahwa terdapat delapan faktor yang mempengaruhi terhadap layanan di dalam pusat kebugaran. Kedelapan faktor tersebut adalah sebagai berikut: (a) aksesibilitas, (b) tata letak fasilitas, (c) desain fasilitas, (d) kondisi peralatan, (e) suasana, (f) sistem fasilitas, (g) petunjuk penggunaan, dan (h) faktor sosial.

\section{b. Tingkat Kepuasan Pengunjung Terhadap Layanan Manajemen Wellness Center pegawai PT. Pertamina Gas Jakarta}

Beberapa catatan dari hasil evaluasi terkait dengan kepuasan pengunjung adalah disebabkan beberapa faktor diantaranya adalah fasilitas yang masih minim, kebersihan yang belum maksimal dan yang paling utama adalah program-program di Wellnes Center belum berjalan dengan baik. adanya program yang tiba-tiba dihilangkan karena sepi pengunjung sehingga secara tidak langsung menyebabkan ketidakpuasan pengunjung yang sudah rutin mengikuti program tersebut. Dalam rangka menguji kefektifan sebuah program fitness salah satunya adalah kepuasan pengunjung. Menurut Irfandi \& Rahmat, (2017:27) Kriteria keefektifan meliputi: Produksi, Efisiensi, Kepuasan, Keadaptasian dan Pengembangan. Beberapa hasil penelitian yang menjelaskan tentang kepuasan pengunjung fitness salah satunya adalah peningkatan kinerja dan kualitas pelayanan. Menurut (Dianto, 2014) Nilai rata-rata total importance performance yang diperoleh 96,3\% yang berarti secara keseluruhan pelayanan The Body Art Surabaya kepada konsumen belum memuaskan. Sehingga dapat ditarik kesimpulan bahwa secara menyeluruh kinerja berada pada kriteria sangat baik dan harapan konsumen berada pada kriteria sangat tinggi. Namun kualitas pelayanan The Body Art dirasa sedang atau biasa saja sehingga belum mampu memberikan kepuasan pada konsumen.

Menurut (Mohamad Fakhri Afriansyah, 2016) menjelaskan bahwa dimensi Bukti Langsung (Tangibless) sebesar $85 \%$ yang berarti sangat memuaskan, dimensi Kehandalan (Reliability) sebesar 83,6\% yang berarti sangat memuaskan, dimensi Daya Tanggap (Responsiveness) sebesar 81,6\% yang berarti sangat memuaskan, dimensi Jaminan (Assurance) sebesar 83,8\% yang berarti sangat memuaskan, dan dimensi Empati (Empatby) sebesar 81,4\% yang berarti sangat memuaskan. Sehingga dapat diketahui secara keseluruhan bahwa tingkat persentase kepuasan members fitness di Balai Kesehatan Olahraga dan Pusat Informasi Pencegahan Penyakit 
Metabolik (BKOR-PIPPM) Kabupaten Lumajang sebesar 83,08\% yang berarti sangat memuaskan.

Berdasarkan hasil evaluasi produk secara keseluruhan yang meliputi: realisasi pengunjung dan tingkat kepuasan pengunjung pada Wellnes Center diperoleh skor rata-rata sebesar 37,41\% menunjukkan bahwa evaluasi produk manajemen Wellness Center pegawai PT. Pertamina Gas Jakarta termasuk ke dalam kategori sangat kurang $(\leq-40 \%)$. Maka dapat disimpulkan bahwa komponen-komponen evaluasi yang terdapat pada tahapan produk ini dinilai masih kurang dalam pelaksanaan manajemen Wellness Center pegawai PT. Pertamina Gas Jakarta.

\section{REFERENSI}

Agung Sunarno. (2016). "Evaluasi Pogram Pembinaan Intensif Komite Olahraga Nasional Indonesia Sumatera Utara tahun 2009-2012". Jurnal Ilmu Keolahragaan, 15(1), 1-26. https://doi.org/10.1002/app5.68.

Almalki, S. (2016). Integrating Quantitative and Qualitative Data in Mixed Methods Research_Challenges and Benefits. Journal of Education and Learning, 5(3), 288. https://doi.org/10.5539/jel.v5n3p288.

Arikunto, S., \& Jabbar, C. S. A. (2009). Evaluasi Program Pendidikan: pedoman teoretis praktis bagi mahasiswa dan praktisi pendidikan. Jakarta: Bumi Aksara.

Aris, Irnanda; Utama, A. (2015). The Effect Of Service Quality Toward Customer Satisfaction On Helios. Jurnal of Business and Management Sciences, 2(3), 2928-2938.

Busyairi, M., Ode, L., \& Safar, A. (2014). "Produktivitas Kerja Karyawan”. Jurnal Ilmiah Teknik Industri, 13(09), 112-124.

Chaddha, S. (2016). "Evaluation of a Training Programme: Case Study of a State ATI". International Journal of Management and Commerce Innovations, 4(1), 479-490. Retrieved from www.researchpublish.com

Cori, C., Paramita, P., \& Wijayanto, A. (2012). "Pengaruh Keselamatan Dan Kesehatan Kerja Terhadap Prestasi Kerja Karyawan Pada Pt . Pln (Persero) Apj Semarang”. Jurnal Administrasi Bisnis, 1, 1-11.

Darodjat dan Wahyudhiana M. (2015). Model Evaluasi Program Pendidikan. ISLAMADINA, XIV, $1-28$.

Dianto, A. R. (2014). Analisis Tingkat Kepuasan Konsumen Terhadap Kualitas Pelayanan Di The Body Art Fitness \& Aerobic Surabaya. Jurnal Kesehatan Olabraga, 2(2), 225 - 236.

Eric Soebari. (2016). Kompetensi Orientasi Pelayanan Personal Trainer Atlas Sports Club Surabaya. Jurnal Kesehatan Olahraga, 06(2). 
Firdaus, K. (2011). Evaluasi Program Pembinaan Olahraga Tenis Lapangan di Kota. Padang: Media Ilmu Keolahragaan Indonesia, 1.

Gas, P. P. (2017). Annual Report PT Pertamina Gas 2017. Retrieved from http://www.pertagas.pertamina.com/\%0Ahttp://www.pertagas.pertamina.com/ourprofileid-ID

Handoko Dwi Purnomo. (2017). "Kepuasan Member Pada Program Persona Trainer Di Celebrity Fitness Supermall". Jurusan Pendidikan Kesehatan Dan Rekreasi, Fakultas Ilmu Keolabragaan, Universitas Negeri Surabaya, 1-9.

Haryadi, W. M., Pratidina, G., \& Seran, M. G. (2016). "Studi manajemen pembinaan olahraga sepak bola di klub persatuan sepak bola kota bogor oleh kantor pemuda dan olahraga kota bogor". Jurnal Geovernansi, 2(April), 41-46.

Hasibuan, M. (2014). Manajemen Dasar, Pengertian dan Masalah. Jakarta: Bumi Aksara.

Irfandi, \& Rahmat, Z. (2017). Manajemen Penjas dan Olabraga. Surakarta: Yuma Pustaka.

Jane, D. . (2005). Evaluation Methodology Basics: The Nuts, and Bolts of Sound Evaluation. California: Sage Publications.

Kasmir. (2010). Pengantar Manajemen Keuangan. Jakarta: Kencana.

Kusuma, B., \& Efranto, R. Y. (2011). “(Studi Kasus Pada Perusahaan PT . Petrokimia Gresik) The Influence Of Occupational Health And Safety Against (Case Study Perusahaan PT . Petrokimia Gresik)". Jurnal Rekayasa Dan Manajemen Sistem Industri, 2(5), 1100-1111.

Lukito, F., \& Brahmana, K. M. R. (2007). Pengarub Workout Motives Dan Perfromance Service Quality (Sermerf) Terhadap Willingness To Pay Premium Melalui Variabel Attitude, Pada Fitness Center Yang Berada Pada Mall Di Surabaya. Universitas Kristen Siwalankerto.

Mahmudi, I. (2011). CIPP: Suatu Model Evaluasi Program Pendidikan. Jurnal At-Ta'dib, 6(1).

Mohamad Fakhri Afriansyah. (2016). Tingkat Kepuasan Members Fitness Terhadap Pelayanan Di Tempat Kebugaran Balai Kesehatan Olahraga Dan Pusat Informasi Pencegahan Penyakit Metabolik (Bkor-Pippm) Kabupaten Lumajang. Jurnal Kesehatan Olahraga, 06(2).

Pelana, R. (2017). Persepsi Atlet Terhadap Sdm Pplm Tentang Prestasi Atlet. Gladi Jurnal Ilmu Keolabragaan, 7(2), 765. https://doi.org/10.21009/gjik.072.03

Presiden Republik Indonesia. (2007). Peraturan Pemerintah Republik Indonesia Nomor 16 Tabun 2007 Tentang Penyelenggaraan Keolabragaan. Jakarta.

Ridhotulla, S., \& Jauhar, M. (2015). Pengantar Manajemen. Jakarta: Prestasi Pustaka.

Rumah Sakit Pertamina Jaya. (2015). Program Employe Exercice Center. Jakarta.

Simanjuntak, P. J. (2005). Manajemen dan Evaluasi Kinerja. Jakarta: Lembaga Penerbit Fakultas Ekonomi Universitas Indonesia. 
Stufelbeam, D. L., \& Chris LCoryn. (2014). Evaluation Theory Model, and Application. United States Of America: Jossey Bass.

Sujadi, Eko., Meditamar, Muhd. Odha., Ahmad, Bukhari., Rahayu, Anita. (2018). Pengaruh Konsep Diri dan Locus of Control Terhadap Motivasi Berprestasi. Educational Guidance and Counseling Development Jounal, 1 (1): 32-51. dx.doi.org/10.24014/egcdj.v1i1.4808

Sujadi, Eko Sujadi., Ayumi, Rinda Tri., Indra, Syaiful., Sumarto., MRA, Raja Rahima. (2018).Layanan Konseling Kelompok dengan Menggunakan Pendekatan Cognitive Behavioral untuk Membentuk Internal Locus of Control. Jurnal Fokus Konseling, 2 (2): 176184. https://doi.org/10.26638/jfk.626.2099

Sule, E. T., \& Saefullah, K. (2012). Pengantar Manajemen. Jakarta: Kencana.

Tae Kim, K., Bae, J., Kim, J.-C., \& Lee, S. (2016). The Servicescape in the Fitness Center: Measuring Fitness Center's Services. International Journal of Sport Management, Recreation \& Tourism, 21, 1-20. https://doi.org/10.5199/ijsmart-1791-874x-21a

Tiantong \& Tongchin. (2013). A Multiple Intelligences Supported Web-based Collaborative Learning Model Using Stufflebeam's CIPP Evaluation Model. International Journal of Humanities and Social Science, 3(7), 157.

Torang, S. (2014). Organisasi \& Manajemen (Prilaku, Struktur, Budaya \& Perubahan Organisasi). Bandung: Alfabeta.

Umam, K. (2012). Manajemen Organisasi. Bandung: Pustaka Setia.

Vebrianto, R. (2018). Pengaruh Lingkungan Negatif Terhadap Kedisiplinan Siswa SD Negeri 134 Pekanbaru. Journal of Natural Science and Integration, 1(2), 221-228.

Wahidah, I. (2013). Kontribusi Manajemen Fasilitas Dan Mutu Layanan Terhadap Prestasi Olahraga Sepakbola. FKIP UNSIL Tasikmalaya, 01.

Wahyuni, N., Suyadi, B., \& Hartanto, W. (2018). Pengarub Keselamatan Dan Kesehatan Kerja ( K3 ) Terhadap Produktivitas Kerja Karyawan Pada Pt. Kutai Timber Indonesia (Studi Kasus Pada PT. Kutai Timber Indonesia Kota Probolinggo ). 12, 99-104. https://doi.org/10.19184/jpe.v12i1.7593

Wibowo. (2014). Manajemen Kinerja. Jakarta: PT. Raja Grafindo Persada.

Wirawan. (2012). Evaluasi: Teori, Model, Standar, Aplikasi dan Profesi. Jakarta: PT. Rajagrafindo Persada.

Yunida, E., Sugiharto, \& Soenyoto, T. (2017). Manajemen Pembinaan Merdeka Basketball Club (MBBC) Pontianak Kalimantan Barat Tahun 2016 Abstrak. Journal of Physical Education and Sports, 6(2), 125-132. 